\title{
O PEIXINHO DOURADO E 0 SAMURAI: SUJEITO EMPÍRICO E SUJEITO EPISTEMOLÓGICO EM MICHEL FOUCAULT
}

\author{
Luciano Oliveira
}

Professor aposentado de Sociologia Jurídica da Faculdade de Direito do Recife, e professor do Departamento de Ciências Jurídicas da Universidade Católica de Pernambuco. Recife, PE. Brasil. E-mail: <jlg05283@gmail.com> http://dx.doi.org/10.1590/ 0102-6445015-046/99

Mamãe, o que é que um peixe pensa? (Michel Foucault, CRiança, Dirigindo-SE a Mme. FouCAULT $)^{1}$

Quem já leu Vigiar e punir não esquece o seu espetacular começo. Em 1757, na Praça da Grève, em Paris, um camponês francês de nome Damiens (um quase débil mental que feriu levemente o rei Luís XV com um canivete) sofreu durante horas toda a "arte das sensações insuportáveis" (Foucault, 1977, p. 16) exercida sobre seu corpo pelo carrasco de Paris, até ser esquartejado, ainda vivo, por quatro cavalos que foram atados aos seus braços e pernas. O livro de Foucault abre com uma minuciosa descrição do evento, transcrita de jornais da época. Para um leitor moderno, é chocante. Mas a abertura é espetacular inclusive no sentido literal de um espetáculo dado ao público. O famoso aventureiro Giacomo Casanova, por exemplo, estava presente num dos balcões que davam para a Praça da Grève naquele

1 Apócrifa ou não, a informação encontra-se em Veyne (2008, p. 209). 
dia, a fim de assistir ao que foi uma atração com grande afluência de público. Casanova relata nas suas Memórias que tinha uma "amiga" sentada no colo e conta como fez, discretamente e com a cumplicidade dela, para atingir seus objetivos por baixo de suas anáguas - e pede desculpas ao leitor por não dar uma descrição do que se passava no cadafalso, porque "tais horrores são uma afronta à natureza" (Casanova, 1946, p. 40).

O célebre veneziano era um homem ilustrado. Com isso, quero dizer: um homem do Século das Luzes. Sua sensibilidade não era um caso isolado. Afinal, apesar dos espectadores ululantes em torno do cadafalso e, para os mais afortunados, os balcões, estamos no século de Voltaire e, mais tarde, da Declaração dos Direitos do Homem e do Cidadão, em 1789. Numa palavra, no século do amplo movimento político e intelectual conhecido entre nós como Iluminismo, no bojo do qual a abolição da tortura e o fim das penas cruéis como a 16 que Casanova não ousou descrever figuravam entre as reivindicações que eram endereçadas ao Ancien Régime.

Sete anos depois do suplício de Damiens, em 1764, surge o livro de Beccaria, Dos delitos e das penas, um vigoroso libelo contra as torturas e os suplícios que fez do seu autor o nome mais importante da corrente reformista que veio a ser chamada de "humanismo penal". O pequeno livro de Beccaria catalisou as demandas contra a crueldade de uma justiça que torturava e esquartejava corpos e tornou-se rapidamente um sucesso junto ao público ilustrado da época. Seu autor, apesar de italiano e de escrever em sua língua natal, era um representante típico do credo iluminista, e seu livro, vertido para o francês, foi lido com atenção em toda a Europa. Ainda hoje seu nome é venerado nos cursos de direito mundo afora, e o "humanismo penal", malgrado suas promessas não cumpridas, continua figurando como horizonte de sentido para os militantes dos direitos humanos que se batem contra a desumanidade da pena carcerária que substituiu os suplícios em 
praça pública. Mas, apesar das decepções, seria inimaginável para esses militantes, herdeiros longínquos do Iluminismo, a volta aos métodos do Ancien Régime. E o que Vigiar e punir tem a ver com isso? Ocorre que, depois do choque que as páginas iniciais do livro nos causam, vem em seguida um estranhamento e tanto. É que o texto de Foucault ostenta uma espécie de fascinação pelos horrores dos suplícios. Vigiar e punir, com efeito, empreende uma leitura tão anti-humanista da obra dos reformadores que não é surpreendente que alguns tenham "erroneamente interpretado o livro de Foucault como uma apologia dos tempos passados" (Vidal-Naquet, 1986, p. 16). Em vários momentos do texto foucaultiano aparece um indisfarçável entusiasmo pelas "emoções de cadafalso" em que a multidão se deleita, o que é sempre motivo de temor por partes das autoridades, pois há sempre o perigo de que o "carnaval" degenere em revolta. Passo-lhe a palavra: "O suplício permite ao condenado essas saturnais de um instante, em que nada mais é proibido nem punível. Ao abrigo da morte que vai chegar, o criminoso pode dizer tudo, e os assistentes aclamá-lo" (Foucault, 1977, p. 55; grifos meus).

"Saturnais de um instante" - é belo, sem dúvida! Contraposto a isso, a monotonia e a discrição do direito penal moderno, que paulatinamente aboliu o espetáculo da punição, recebem um tratamento que enfatiza o tédio burocrático em que se dão as novas formas de punir. Foucault expõe um em seguida ao outro, e sem qualquer transição, o suplício de Damiens e o regulamento do cotidiano de uma prisão francesa de 1830, onde os golpes do carrasco no corpo do condenado foram substituídos pela monotonia de intermináveis horas dedicadas a trabalho, silêncio e orações por parte dos presos. Diz ele:

O afrouxamento da severidade penal no decorrer dos últimos séculos é um fenômeno bem conhecido dos historiadores do direito. Entretanto, foi visto, durante muito tempo, de forma geral, como se fosse fenômeno 
quantitativo: menos crueldade, menos sofrimento, mais suavidade, mais respeito e "humanidade". Na verdade, tais modificações se fazem concomitantes ao deslocamento do objeto da ação punitiva. Redução de intensidade? Talvez. Mudança de objetivo? Certamente (Foucault, 1977, p. 20).

Esclarecendo o "afrouxamento" e a "mudança”, ele escreve que "à expiação que tripudia sobre o corpo deve suceder um castigo que atue, profundamente, sobre o coração, o intelecto, a vontade, as disposições" (Foucault, 1977, pp. 20-21). Mas por quê? No ínterim entre 1757 e 1830 (pouco mais de setenta anos, nada mais do que um bocejo do Tempo), o que teria acontecido? Para Foucault, é simples: a substituição dos suplícios por métodos menos sanguinários como a prisão não teria constituído senão o subproduto de um novo tipo de sociedade, que ele chama de "disciplinar". Foucault sustenta que a verdadeira finalidade da reforma era dotar a lei penal de uma racionalidade que ela não tinha, visando torná-la mais eficaz. Para ele, o fim dos suplícios e a generalização da prisão não foram nada mais do que uma nova "estratégia para o remanejamento do poder de punir, de acordo com modalidades que o tornam mais regular, mais eficaz, mais constante e mais bem detalhado em seus efeitos" (Foucault, 1977, p. 75). Ele parece comprazer-se em chocar o leitor ingênuo, aquele que sempre pensou que a punição pela prisão era, apesar de tudo, mais humana (em todo caso, menos desumana) do que os suplícios em praça pública - num certo sentido, todos nós!

Há bastante verdade na tese foucaultiana. De fato, uma leitura atenta de um clássico como Dos delitos e das penas detecta inúmeros argumentos utilitaristas usados por Beccaria. A meu ver, seria algo equivalente ao que diz modernamente a Anistia Internacional quando se posiciona contra a pena de morte valendo-se, ao lado dos argumentos huma- 
nitários, de estatísticas que mostram que a sua abolição não faz subir a taxa de criminalidade. Mas disso somos autorizados a concluir que todos os que lutam contra a pena capital são movidos apenas por essa forma calculista de pensar? Foucault, em nenhum instante, considera a possibilidade de que Beccaria e os demais reformadores pudessem estar agindo por um genuíno impulso de sensibilidade humana - o que, claro, não exclui também a motivação utilitária, à qual ele se aferra de modo unilateral: "Essa racionalidade 'econômica' é que deve medir a pena e prescrever as técnicas ajustadas. 'Humanidade' é o nome respeitoso dado a essa economia e a seus cálculos minuciosos" (Foucault, 1977, p. 84). As aspas na palavra Humanidade, repetidas mais de uma vez, dão conta da ironia foucaultiana. Para ele, não podemos nos abandonar ingenuamente à ficção idealista de uma sensibilidade que não suporta o espetáculo dos suplícios como explicação para a sua abolição. Vá lá!

Mas o mais curioso - e, à primeira vista, desconcertante - é o fato de que, enquanto indivíduo, Foucault como que partilhava essa opinião ingênua. Infatigável militante dos direitos humanos, ele teve várias vezes a oportunidade de pronunciar palavras nas quais dificilmente o leitor reconheceria o autor irônico de Vigiar e punir. Em 1981, chegou a redigir o esboço do que seria uma nova declaração de direitos humanos, no contexto da luta em favor dos boat-people - como ficaram conhecidos os fugitivos do Vietnã do Sul depois da vitória dos vietnamitas do Norte na mais emblemática guerra da segunda metade do século XX. É curioso ler esse documento. Deixando de lado os pressupostos sobre a natureza humana, Foucault vai direto ao ponto: "A desgraça dos homens [...] funda um direito absoluto a se levantar e a se dirigir àqueles que detêm o poder." E enuncia um "novo direito: o dos indivíduos privados de intervir efetivamente na ordem das políticas e das estratégias internacionais". Mas qual seria o fundamento desse "direito absoluto"? Foucault, 
para quem nenhum essencialismo humanista faria sentido, não dá importância à questão: "Somos apenas homens privados, sem outro título para falar”. E continua: "Quem, portanto, nos incumbiu? Ninguém. E é isso justamente que constitui nosso direito." 2 .

Ora, será preciso lembrar que essa visão do indivíduo como um ser humano dotado de direitos oponíveis ao Estado foi um dos grandes temas do Iluminismo tão maltratado teoricamente por nosso autor? Teoricamente, enfatizo. Na prática, Foucault, mesmo sem fazer menção a direitos naturais ou a qualquer tipo de conceito universal, simplesmente agia. Por quê? Porque - como teria ele mesmo dito ao seu amigo Paul Veyne (2008, p. 180) a propósito dos pavilhões de segurança máxima das prisões francesas - "quando é insuportável, não se suporta mais". E pronto. Uma pergunta, porém, nos importuna: como isso é teoricamente possível? A ênfase no advérbio, mais do que 20 chamar a atenção para o que parece ser uma inconsistência - quando não uma contradição - do autor, quer sugerir a hipótese de que a questão se resolve (e só se resolve) num plano, por assim dizer, teórico. É a hipótese da disjunção entre sujeito empírico e sujeito epistemológico anunciada no subtítulo, para a qual me volto.

Sujeito. Eis uma dessas palavras que de vez em quando se tornam reluzentes nos arraiais das ciências sociais e humanas e depois desaparecem, às vezes sem deixar rastros. Hoje em dia, se fala pouco sobre o sujeito. Houve uma época, entretanto, em que questões como a "morte do sujeito" e, depois, a "volta do sujeito", animavam grandes polêmicas. Nelas, Foucault era um dos nomes mais destacados. Primeiro porque teria sido um dos grandes responsáveis por seu suposto desaparecimento; depois, porque teria sido um dos mais importantes corifeus de sua

2 Publicado no jornal Libération, 30/06, 1 de julho de 1984, p. 22. 
reabilitação. Foi um debate típico dos anos 1960 até algum momento dos anos 1980. Mas essa tipicidade refere-se mais ao continente - o termo sujeito - do que ao conteúdo. O debate já tinha uma longa história dentro das questões suscitadas, entre outros, pelo marxismo e suas extenuantes querelas sobre o papel do indivíduo na história. Mas, a bem dizer, é um debate coetâneo à própria sociologia, existente desde pelo menos a reação que Durkheim havia suscitado com conceitos como "fato social", capazes de pôr em xeque noções como liberdade e responsabilidade, sem as quais os princípios da moral e do direito parecem soçobrar. Na via inversa, conceitos como o de "estrutura social" põem em xeque noções como indivíduo, sujeito etc. $\mathrm{O}$ debate, no vai-e-vem das modas conceituais, prossegue hoje com a noção de agência... Mas voltemos ao sujeito, à sua morte, e a Foucault.

A questão aparece explicitada na obra que, lançada dez anos antes de Vigiar e punir, granjeou para Foucault um prestígio internacional: As palavras e as coisas. É a famosa fase "estruturalista" de Foucault, na qual o que lhe interessa são os "códigos fundamentais de uma cultura aqueles que regem sua linguagem, seus esquemas perceptivos, suas trocas, suas técnicas, seus valores, a hierarquia de suas práticas". Tais códigos "fixam, logo de entrada, para cada homem, as ordens empíricas com as quais terá de lidar e nas quais se há de encontrar" (Foucault, 1999, p. xvi). Esse é o período onde a recusa da noção de sujeito é de regra na rive gauche parisiense, uma vez que, como o homem das grandes Declarações e do humanismo tradicional, ele é igualmente produzido por tais configurações. Logo no começo do livro, Foucault antecipa-se a possíveis objeções, desqualificando eventuais candidatos a criticá-lo: "o homem - cujo conhecimento passa, a olhos ingênuos, como a mais velha busca desde Sócrates - não é, sem dúvida, nada mais que uma certa brecha na ordem das coisas" 
(Foucault, 1999, p. xxi; grifos meus). Caminhando para o fim, chega ao escárnio puro e simples:

A todos os que pretendem ainda falar do homem, de seu reino ou de sua liberação, a todos os que formulam ainda questões sobre o que é o homem em sua essência, a todos os que pretendem partir dele para ter acesso à verdade [...], a todas essas formas de reflexão canhestras e distorcidas, só se pode opor um riso filosófico (Foucault, 1999, p. 473).

E, na última página, defrontamo-nos com o famoso presságio do seu desvanecimento "como, na orla do mar, um rosto de areia” (Foucault, 1999, p. 536). Essa postura, ainda que de forma menos evidente, persistirá no período que virá a seguir, o chamado período genealógico, e só será de fato abandonada na sua última fase, que alguns chamarão de "hermenêutica do sujeito", título extraído de um dos 22 seus últimos cursos, nos quais, saindo do seu universo temporal habitual (o período entre a Idade Clássica e o século XIX) e do seu tema de predileção na fase genealógica (a constituição dos "sujeitos sujeitados" através de processos de normalização), Foucault se volta para a Grécia e a Roma antigas e passa a examinar o processo de autoconstituição de sujeitos livres através de uma "estilística da existência" (Rouanet, 1997, p. 215). Mas algo da atitude estruturalista por excelência - aquela que se reporta a estruturas bastando-se a si mesmas e, portanto, produzindo os "sujeitos" que as fazem funcionar - permanece em Vigiar e punir.

Como é recorrente em trabalhos de orientação estruturalista lato sensu, defrontamo-nos aqui com o vezo de uma história que se faz pela superposição de camadas estranhas umas às outras e que percorre as análises históricas de Foucault, mesmo depois de sua breve fase estruturalista stricto sensu. Na "sociedade disciplinar" erigida ao longo do século XIX, os suplícios desaparecem e a prisão generaliza-se de 
tal forma a ponto de praticamente se tornar sinônimo de pena. Não há continuidade, mas ruptura entre uma coisa e outra. Foucault como que mimetiza essa ruptura nas páginas iniciais de Vigiar e punir ao apresentar, lado a lado e na total indiferença do autor, os horrores de uma sessão de esquartejamento contraposta à monotonia de uma prisão - como se estivéssemos simplesmente diante da substituição de um regime punitivo por outro. Sem dúvida, estávamos. Mas, movido pelo afã em pôr a nu os interesses utilitaristas encobertos pela apologética dos reformadores que, afinal, produziram o muito pouco humano mundo carcerário, Foucault cita nomes e não negaceia uma ironia devastadora sempre que fala do reformismo de um Jeremy Bentham, idealizador do que seria o dispositivo por excelência da "sociedade disciplinar": o panóptico - cuja aplicação, mesmo falha, teve na prisão seu lugar privilegiado. Eis como Foucault o descreve:

O princípio é conhecido: na periferia uma construção em anel; no centro, uma torre [...]; a construção periférica é dividida em celas, cada uma atravessando toda a espessura da construção; elas têm duas janelas, uma para o interior, correspondendo às janelas da torre; outra, que dá para o exterior, permite que a luz atravesse a cela de lado a lado. Basta então colocar um vigia na torre central, e em cada cela trancar um louco, um doente, um condenado, um operário ou um escolar. Pelo efeito da contraluz, pode-se perceber da torre, recortando-se exatamente sobre a claridade, as pequenas silhuetas cativas nas celas da periferia (Foucault, 1977 , p. 177).

Bentham formulou a ideia do panóptico em 1787, numa série de cartas depois reunidas em volume. A versão coligida tem por subtítulo “A Casa de Inspeção”, e não esconde as várias utilidades a que se destina o "novo princípio [...], 
aplicável a qualquer sorte de estabelecimento no qual pessoas de qualquer tipo necessitem ser mantidas sob inspeção; em particular às casas penitenciárias”. Num lance de publicidade, elenca outros usos: "casas de indústria, casas de trabalho, casas para pobres, manufaturas, hospícios, lazaretos, hospitais e escolas" (Bentham, 2000, p. 13.) O autor exulta com essa espécie de elixir da longa vida a ser ministrado à sociedade industrial nascente: "A moral reformada; a saúde preservada; a indústria revigorada; a instrução difundida; os encargos públicos aliviados; a economia assentada, como deve ser, sobre uma rocha [...], tudo por uma simples ideia de arquitetura!" (p. 15). Em 1791, a Assembleia Nacional Constituinte francesa, num momento de fervor revolucionário e de entronização da Razão, publicou o Panoptique de Bentham na Imprensa Nacional. Nisso, Foucault está certo: a prisão é, entre outras coisas, um dos subprodutos do Iluminismo.

24 Utopia estranha, sem dúvida, mas também "humanista" a seu modo. Segundo Bentham, ela seria interessante até para os próprios malfeitores, que veriam como "evidente" que a "tendência coercitiva" do dispositivo seria compensada por sua "tendência benevolente", na medida em que "tornará desnecessária aquela inexaurível fonte - muitas vezes desnecessária e sempre impopular - de desproporcional severidade, para não dizer tortura, representada pelo uso de ferros" (Bentham, 2000, p. 30). "O sonho de uma maldade" - foi como Foucault (1977, p. 197) chamou esse dispositivo de disciplina. Para ele, o mais grave é que essa estonteante "ideia de arquitetura" teria, do nascimento à morte, estendido seu manto sobre a sociedade inteira. Como disse numa famosa afirmação, "somos bem menos gregos que pensamos", pois estamos todos presos "na máquina panóptica, investidos por seus efeitos de poder que nós mesmos renovamos, pois somos suas engrenagens" (p. 190; grifos meus). Daí a famosíssima interrogação com 
que encerra o capítulo de Vigiar e punir dedicado ao "panoptismo" onipresente na sociedade disciplinar: "devemos ainda nos admirar que a prisão se pareça com as fábricas, com as escolas, com os quartéis, com os hospitais, e todos se pareçam com as prisões?" (p. 199).

A finalidade disso tudo, já se sabe: produzir sujeitos "politicamente dóceis e economicamente produtivos" - como assinala Foucault. E se, em relação ao regime punitivo do Ancien Régime, ele demonstra uma espécie de fascínio, em relação ao novo regime ele não esconde sua antipatia - para dizer o mínimo. Mas aí é que reside o problema. Ator mais do que ativo na militância em favor dos direitos humanos e outras causas correlatas, Michel Foucault sempre ouviu a conhecida cobrança: se todos somos engrenagens da máquina panóptica, de onde extrairíamos a disposição para criticá-la? Essa é uma pergunta da qual ele preferia se esquivar. Mas ela continua a nos causar espécie: sendo Foucault um arrojado militante contra torturas, detenções arbitrárias e pena de morte, como vê-lo como um simples adversário do humanismo penal tout court? Há que se ver nas suas aporias, creio, algo de mais complexo: uma disjunção, digamos assim, entre sujeito empírico e sujeito epistemológico. A disjunção foi-me sugerida pela leitura do belo livro de erudição, afeto e saudade que Paul Veyne dedicou ao amigo, onde estão as imagens do peixinho dourado e do samurai, uma e outra conectadas a uma terceira: a de um aquário.

A imagem quer dizer que, a exemplo dos peixinhos que lá estão, estamos, desde que nascemos, presos num aquário sem disso nos darmos conta, sem sequer ver-lhes as paredes. Porém, à diferença (suposta, evidentemente) dos peixinhos, e apesar da advertência de que "somos bem menos gregos que pensamos", pensamos! E não pensamos todos do mesmo jeito. Na Praça da Grève, em 1754, a multidão que se derretia de prazer em torno do cadafalso erigido para Damiens pertencia a um aquário dominante na época. Mas Casanova, 
que era da mesma época, estava interessado em outro tipo de prazer, e seu estômago ficou embrulhado pelo que seus olhos não podiam deixar de entrever e seus ouvidos de ouvir. Seria ele um peixinho livre em relação às paredes invisíveis do aquário que prendia os espectadores embaixo do balcão? Certamente. Mas ele estava preso por outras paredes que igualmente não via, imerso num novo aquário em vias de constituir-se. Ele, mas também Beccaria e, antes deles, um Voltaire. Era o aquário onde se mesclavam o humanismo penal, os direitos do homem e o capitalismo nascente - um aquário de tipo novo que Foucault chamará de "sociedade disciplinar". Como os aquários não são os mesmos, inútil valer-se dos valores de um para julgar os outros. $\mathrm{O}$ regime penal do Ancien Régime fazia parte de um aquário; o "humanismo penal", de outro. Só isso. Mas, se existem os peixinhos dourados, existem também os samurais.

Essa figura, também da lavra de Paul Veyne, aparece 26 em razão de uma pergunta que naturalmente surge quando pensamos na existência de vários aquários que se sucedem ao longo da história: se estamos todos presos ao aquário do tempo em que vivemos, e cujas paredes nem vemos, como é possível que surjam novos aquários? A resposta de Veyne é a de que isso ocorre sob a pressão "de novos acontecimentos [...] ou ainda porque um homem inventou um novo discurso e obteve sucesso". Um novo discurso inventado por homens? Não parece à primeira vista uma linguagem na qual o Foucault estruturalista ou genealogista se reconheceria. Mas se assim é, então existe a possibilidade de que vez por outra surja, dentro do aquário do momento, uma criatura "anormal" - um termo bem foucaultiano, aliás - no meio dos peixinhos: justamente aquilo que Veyne (2008, p. 11), pensando na silhueta esguia e no manejo destro da pena por parte do seu amigo, chamou de samurai. Foucault era um deles. E ele, sem dúvida, foi também um inventor de novos aquários. Mas por que isso acontece, ou por que surgem novos acontecimentos 
inaugurais, essa é uma questão em aberto - e certamente não serei eu a me propor respondê-la.

Recapitulando e resumindo: os aquários existem, e nascemos num deles. Isso faz de todos nós, pelo menos a princípio, e no princípio, peixinhos dourados - sujeitos empiricos, como os estou chamando. Mas nos aquários também surgem, de quando em vez, "anormais" como Beccaria, mas também Foucault - sujeitos epistemológicos, como os estou nomeando. Como sujeitos empíricos, somos todos "sujeitados"; como sujeitos epistemológicos, tomamos consciência da historicidade dos processos de sujeição. O peixinho Michel rachou o aquário em que nasceu. Na execução de sua tarefa, porém, o samurai Foucault muitas vezes trocou a precisão pela fúria ao brandir o sabre. Era do seu temperamento, era o seu estilo.

Essa seria uma das maneiras de resolver a aparente aporia entre sua epistemologia e sua militância: não levar tão a sério certas frases brilhantes e marcantes de Foucault, como aquela que nos adverte de que não somos gregos. Reconsideremos a frase. Ela é desesperadora, mas está num livro, Vigiar e punir, em que seu autor também lembra que o exercício do poder choca-se sempre com "resistências". Poder e contrapoder, em Foucault, aparecem quase sempre geminados. Afinal, se é preciso disciplinar, é porque há corpos indisciplinados; se é preciso adestrar, é porque há almas renitentes - e assim por diante. É verdade, porém, que a mira de Foucault - pelo menos do Foucault genealógico - é sempre o poder, o processo de normalização da sociedade moderna. Quando, nas últimas obras, ele se volta para o sujeito como instância dotada de liberdade, faz isso se refugiando na Grécia e na Roma antigas.

Os reproches aos exageros foucaultianos não são novos. Sua primeira grande obra, História da loucura, antes de se transformar em livro, foi uma tese de doutorado que Foucault defendeu na honorável Sorbonne. Na ocasião, a banca, 
como era de se esperar de um trabalho com tal envergadura, aprovou-o com louvor, mas nem por isso os seus julgadores eximiram-se de emitir reservas. Georges Canguilhem, seu orientador, observou um traço de "retórica" em alguns momentos. E o presidente da sessão, o historiador Henri Gouhier, achou o candidato "muito cioso" em "chercher l'effet" (apud Eribon, 1989, p. 139), o que, numa tradução livre, seria algo como "procurar impressionar". De fato, parece haver traços marcantes dessa intenção em momentos como os que Foucault denuncia o "aprisionamento moral" a que a razão, na modernidade, teria submetido o louco em termos que, comparativamente, fazem das masmorras imundas onde eles eram jogados na Idade Clássica um espaço de liberdade - ainda que o próprio Foucault cite casos como o de um capitão inglês que passou quarenta anos acorrentado numa cela (Foucault, 1987, p. 472). Como, afinal, levar muito a sério a observação de 28 que "a cela, as correntes, o espetáculo contínuo, os sarcasmos constituíam para o delírio do doente uma espécie de elemento de sua liberdade"? (p. 490).

Outra saída para a aporia é, ainda que não levando tão a sério certas afirmações cortantes em que Foucault era mestre, considerar que, de fato, uma coisa é o que somos enquanto seres socialmente construídos - e basta pensar na sociologia de um Durkheim para ver que isso nada tem de revolucionário; outra, é considerar que somos seres pensantes e, portanto, capazes de nos desentranharmos dessas determinações. As duas coisas não são incompatíveis. Mas Foucault nunca se preocupou em se explicar. Com o que voltamos à tentativa nesse sentido feita por seu amigo Paul Veyne, com as metáforas do peixinho dourado e do samurai. Eis como Veyne introduz essas imagens:

Tudo que acreditamos saber é limitado à nossa revelia, não conhecemos seus limites e ignoramos mesmo que 
eles existam. No automóvel, quando o homo viator dirige à noite, ele nada pode ver além do alcance dos faróis e, além do mais, frequentemente não distingue até onde vai esse alcance e nem vê que não vê. Mudando de metáfora, somos sempre prisioneiros de um aquário, do qual sequer percebemos as paredes; sendo os discursos incontornáveis, não se pode, por graça especial, perceber a verdade verdadeira (Veyne, 2008, p. 44; grifos meus).

Vale notar que o conceito de "discurso" em Foucault significa mais do que simples enunciados verbais. Ainda que constituído por enunciados, os discursos compreendem também a episteme - outro termo bem foucaultiano dentro da qual são proferidos. Para Paul Veyne, o que Foucault queria dizer é simplesmente que qualquer "objeto em sua materialidade não pode ser separado dos quadros formais através dos quais o conhecemos, e que Foucault, com uma palavra mal escolhida, chamava de 'discurso'" (Veyne, 2008, p. 14; grifos meus). É nesse sentido que o discurso a favor dos direitos humanos, pelo quais Foucault lutou, não é, própria e rigorosamente falando, mais verdadeiro do que o discurso racista, por exemplo; é simplesmente um discurso sobre a condição humana ao qual os indivíduos aderem ou não, por razões que, no fundo, seria vão buscar explicar. François Ewald, seu assistente no Collège de France, escreveu à sua morte que suas intervenções políticas "são indedutíveis de um sistema. Para ele, filosofia e política pertenciam a registros diferentes; não era pensável que um se deduzisse do outro" (Ewald, 1984, p. 20). E Veyne diz o que Foucault não disse, mas talvez subscrevesse:

[...] um discurso com seu dispositivo institucional e social é um status quo que se impõe apenas enquanto a conjuntura histórica e a liberdade humana não lhe substituem por outro; saímos do nosso aquário provisório sob a pressão de 
novos acontecimentos, ou porque um homem inventou um novo discurso e teve sucesso. Mas não mudamos de aquário senão para nos vermos dentro de um novo aquário (Veyne, 2008, pp. 44-45).

"Liberdade humana" em Foucault? Sim, desde que não esqueçamos que "novos acontecimentos" ou um "homem" que propõe algo novo também estão, por seu turno, construindo um novo aquário. Até o ceticismo, categoria na qual Veyne insere seu amigo, seria um deles. O cético, diz ele, seria um "ser duplo":

Desde que pense, ele se mantém fora do aquário e olha os peixinhos que dão voltas dentro dele. Mas como é preciso viver, ele se encontra dentro do aquário, ele mesmo outro peixinho dourado, para decidir que candidato terá seu voto nas próximas eleições. O cético é ao mesmo tempo um observador fora do aquário, que ele põe em dúvida, e um dos peixinhos dourados (Veyne, 2008, p. 11).

O cético chamado Foucault é descrito como um "esguio, elegante e afiado personagem que nada ou ninguém fazia recuar” (Veyne, 2008, p. 11). Daí a imagem do samurai. Mas também o samurai está num aquário:

Este aquário ou discurso é "o que poderíamos chamar um a priori histórico". ${ }^{3}$ Certo, este a priori, longe de ser uma instância imóvel que tiranizaria o pensamento humano, é mutante, e nós mesmo terminamos por mudá-lo. Mas ele é inconsciente: os contemporâneos sempre ignoraram onde se situavam seus próprios limites, e nós mesmos não podemos perceber os nossos (Veyne, 2008, p. 45).

3 Nesta passagem, Veyne está citando o próprio Foucault. 
Mesmo o militante de direitos humanos não pode estar seguro de que detém uma verdade definitiva desprovida de pré-julgamentos - que, aliás, só serão vistos assim sob o farol de um novo discurso desbravando a neblina para o viator. Assim,

[...] certos preconceitos, como a homofobia, estão se desfazendo: hoje reconhecemos a arbitrariedade dessa mentalidade. Mas não teríamos outros preconceitos? Quais? Nossos netinhos saberão depois que tivermos desaparecido, quando eles forem diferentes de nós (Veyne, 2008, p.138).

Assim, o que é insuportável varia de uma época a outra, de um aquário a outro. Depois do aparecimento de Vigiar e punir, num debate com historiadores girando em torno das teses polêmicas contidas no livro, o próprio Foucault colocou a questão em termos do "limiar de tolerância" em relação ao que é "abominável”, numa discussão com o historiador Maurice Agulhon a respeito das "cadeias" de condenados que, ainda na França do século XIX, atravessavam o país a pé, amarrados uns aos outros, em direção às galés onde iam cumprir trabalhos forçados. Eis como Foucault (1977, p. 14) as havia descrito: "condenados com coleiras de ferro, em vestes multicolores, grilhetas nos pés, trocando com o povo desafios, injúrias, zombarias, pancadas, sinais de rancor ou de cumplicidade". Isso chamou a atenção de Agulhon, que, no debate, depois de referir-se a um julgamento do criador do romance social, Victor Hugo ("a cadeia era o horror incomparável"), lembra o contraste entre a descrição "tão colorida" que faz Foucault da procissão de condenados e a sinistra descrição, feita pelo mesmo Foucault, do "carro celular" que a substituiu, observando, ironicamente, que "chega-se quase a duvidar de que o carro tenha sido um progresso". Tomando a palavra, o indigitado se defende: "É preciso dizer que os limiares de intolerância 
mudam. Mas é preciso dizer também que a prisão é hoje abominável, como era a cadeia ontem" (apud Perrot, 1980, pp. 315 e 317 ).

Depois dessa digressão sobre o samurai e seus combates sem "razão", voltemos à querela sobre o sujeito - mais exatamente, aos processos de sujeição de que ninguém parece escapar na sociedade disciplinar, o que faria da militância de Foucault seja uma estratégia do próprio poder agindo à sua - dele, Foucault! - revelia, seja um puro milagre. Nem uma coisa, nem outra: Foucault, como boa parte de nós, simplesmente está imerso em mais de um aquário. Um deles é o do homem comum, que, como lembra Veyne, é chamado às urnas para depositar seu voto; o outro é o do sujeito filho das Luzes ${ }^{4}$ que luta o bom combate contra certos constrangimentos que se tornaram iníquos. Ousaria dizer, coisa que Foucault não diz explicitamente, que nessa segunda água navegamos com uma altivez e uma 32 liberdade que não temos na primeira, haja vista já o próprio fato de que nela mergulhar resulta de uma escolha certamente não isenta de dores. Mas como Foucault é um autor que sempre privilegia, como analista, o primeiro aquário, ele nada tem a dizer, enquanto teórico, sobre os samurais do segundo - incluindo-se aí ele próprio. A propósito do militante Foucault agindo sem se preocupar com as implicações que o teórico Foucault extrairia de sua militância, dou dois exemplos: o primeiro dizendo respeito à prisão; o segundo, à pena de morte.

Sabe o leitor mais avisado que o livro sobre a prisão decorre do seu trabalho no início dos anos 1970 à frente do GIP (Grupo de Informação sobre as Prisões), composto por intelectuais e militantes egressos do Maio de 68, desejosos

\footnotetext{
4 Essa é a opinião de Rouanet (1997, p. 201), para quem Foucault, malgrado tudo, foi um pensador que se insere numa das linhagens das Luzes: a dos "livre-atiradores do Iluminismo, que não falam em nome de nenhuma sociedade e conservam em toda a sua virulência o espírito iluminista original”.
} 
de lançar luz sobre um mundo tão temido quanto desconhecido das pessoas comuns - que, aliás (na França ou no Brasil), preferem ainda hoje desconhecê-lo: o cárcere. O cidadão e intelectual Michel Foucault, ao criar o Grupo, e com isso se lançar num combate contra o que lhe parecia intolerável para os seus valores, não via a si próprio como um agente inconsciente do poder disciplinar azeitando, com sua ação, suas engrenagens. Tanto que chegou a explicitar sua recusa de que seu trabalho em favor dos presos se tornasse um azeite.

É de sua lavra o manifesto de lançamento do GIP, onde se lê: "O objetivo do GIP não é reformista, nós não sonhamos com uma prisão ideal" (apud Eribon, 1989, p. 241). Depois do lançamento do livro sobre a prisão, num debate em torno dos dilemas que suas reflexões colocavam para homens bem intencionados que lutavam por uma prisão mais humana, foi enfático ao dizer que eles "não deviam encontrar nos [seus] livros conselhos ou prescrições que lhes permitiriam saber 'o que fazer'. [...] meu projeto é justamente fazer de maneira que eles 'não saibam mais o que fazer'” (apud Perrot, 1980, p. 53). Apesar disso, ele fazia. No entanto, é lícito se pôr a questão: ao agir com seus amigos e, com isso, melhorar as condições carcerárias dos pavilhões de segurança máxima das prisões francesas, ele não teria, malgrado as resistências teóricas, "humanizado" mais as prisões? - e, ipso facto, ajudado a azeitar o sistema penal do seu país? Os aquários são tenazes!

Sobre a pena de morte, examinemos rapidamente o que ele diz sobre o assunto no primeiro volume da sua trilogia sobre a sexualidade. Uma das teses do livro está explicitada no jogo de equivalências assimétricas que ele faz com os termos viver e morrer, ao conectá-los aos dois tipos de poder de que se ocupa: o "poder soberano" da Idade Clássica e o "biopoder" da Época Moderna. A hipótese foucaultiana é a de que "o velho direito de causar a morte", do primeiro, foi subs- 
tituído por "um poder de causar a vida", do segundo (Foucault, 1984a, p. 130). Num de seus insights, que considero um típico exagero foucaultiano, afirma o seguinte:

A partir do momento em que o poder assumiu a função de gerir a vida, já não é o surgimento de sentimentos humanitários, mas a razão de ser do poder e a lógica de seu exercício que tornaram cada vez mais difícil a aplicação da pena de morte. [...] Para um poder desse tipo, a pena capital é, ao mesmo tempo, o limite, o escândalo e a contradição (Foucault, 1984a, pp. 129-130; grifos meus).

Vê-se aí, de um lado, o renitente anti-humanismo que já havia usado contra Beccaria e os demais reformadores penais, ao desacreditar os "sentimentos humanitários" como uma das causas da abolição da pena capital; de outro, o cacoete tipicamente "estruturalista" de se reportar a estru34 turas que se bastam a si mesmas, exercitando uma "lógica" que chega a desconsiderar o sujeito enquanto instância de ação livre, movido por imperativos da própria consciência. Serei, em seguida, propositadamente ingênuo, ao mesmo tempo que renderei uma homenagem ao militante Michel Foucault: está para ser escrita uma crônica da abolição da pena de morte num país como a França, processo longo e tardio em relação aos padrões europeus, que leve em conta a ação de samurais como... Michel Foucault!

Desde que, no início dos anos 1970, se envolveu com a questão penal, Foucault foi um ativo militante pela abolição da pena de morte - que, ainda em 1976, ano da última execução, sempre pela guilhotina, causou muita celeuma na França. O último executado foi um certo Ranucci - acusado de sequestro, abuso sexual e morte de um garoto -, cuja culpabilidade nunca foi cabalmente demonstrada, restando até hoje a dúvida, a controvérsia e a consciência intranquila do ex-presidente Giscard D'Estaing que, pressionado pela 
opinião pública ávida de sangue, não comutou a pena. Essa atitude do então presidente valeu-lhe a declinação pública de Foucault em comparecer a um jantar de gala no palácio presidencial francês, devido à recusa de D'Estaing em usar o poder de graça para salvar a vida de Ranucci, evento relatado por Veyne (2008, p. 203) ao realçar a militância do amigo pelo fim da pena capital. Quando, finalmente, ocorre a abolição, em 1981, já era o governo do socialista François Mitterrand, e a medida teve no seu ministro da justiça, Robert Badinter, o principal ator - aquele que foi à Assembleia Nacional francesa convencer os últimos recalcitrantes.

Mas Badinter não foi apenas um político mitterrandista. Ao lado disso, ele foi um desses preciosos iluministas franceses da estirpe de um enciclopedista, misto de causídico e intelectual, tendo, como historiador, produzido uma obra importante sobre o sistema penal na França republicana no século XIX. E, detalhe que no contexto não é negligenciável, amigo próximo e cúmplice na militância de Michel Foucault! Como, à vista do combate de ambos, considerar que se a França aboliu a pena de morte é porque um hipostasiado biopoder, impondo sua destinação de "cuidar da vida", estava simplesmente exercendo sua "lógica"?

Não foi o primeiro embate de Foucault contra essa forma extrema de punição. Em setembro de 1975, com o generalíssimo Francisco Franco às vésperas de se despedir desse mundo, a ditadura espanhola ainda tinha ferocidade bastante para condenar onze jovens militantes à pena de morte. Celebridades do mundo artístico, como Yves Montand e intelectuais, como Michel Foucault, se mobilizaram para "fazer alguma coisa", e o primeiro leu uma declaração da lavra do último:

Onze homens e mulheres acabam de ser condenados à morte. Foram condenados por tribunais de exceção e não tiveram direito à justiça. Nem àquela que exige provas para condenar. Nem àquela que dá aos condenados o poder de 
se defender. [...] Sempre lutamos, na Europa, por essa justiça. Hoje é preciso ainda lutar por ela cada vez que é ameaçada. [...] exigimos que as regras fundamentais da justiça sejam respeitadas para os homens da Espanha como para aqueles d'alhures (Foucault apud Eribon, 1989, p. 279).

E, no entanto, três anos antes Foucault tinha se permitido certas diatribes contra "as regras fundamentais da justiça" que hoje soam delirantes. Como boa parte dos intelectuais franceses de esquerda, Michel Foucault também teve seu momento de derrapagem no esquerdismo - essa "doença infantil do comunismo", como diria Lênin. Era o início dos anos 1970 e, na esteira das agitações de 68, grupos de jovens revolucionários tinham aparecido na França e em outros países europeus, notadamente Alemanha e Itália - alguns deles, como o Baader-Meinhof no primeiro e as Brigadas Vermelhas no segundo, tendo partido resolutamente para a luta armada. Era a época da militância no GIP. Foucault estava envolvido com a temática da punição que o levou a Vigiar e punir e reuniu-se, em 1972, com jovens maoistas franceses, também candidatos à sublevação armada, para debater um dos assuntos mais quentes do momento: a justiça popular.

$\mathrm{O}$ interlocutor que mais intervém no debate é Pierre Victor, codinome de Benny Lévy, então revolucionário maoista e principal dirigente do grupo Esquerda Proletária. Anos mais tarde, igual a tantos outros, dará meia-volta e distanciar-se-á do horizonte revolucionário. Mas em 1972, com a maior seriedade do mundo, Pierre Victor especulava sobre o que aconteceria quando sobreviesse a revolução proletária na Europa: "Vou dar um exemplo fictício: é verossímil que não se liquidem todos os patrões, sobretudo em um país como a França" (apud Foucault, 1984b, p. 48). Mesmo com a ressalva de que o exemplo era fictício, o tom do debate - que, aliás, se abre com uma evocação, feita por Foucault, dos famosos "massacres de setembro" promovidos 
pelos revolucionários franceses em 1792 - não era de brincadeira. E se Foucault evoca esses massacres não é para criticar os excessos cometidos pelas massas enfurecidas num momento em que a França estava sendo invadida pelas potências europeias desejosas de sepultar uma revolução que iria meses mais tarde decapitar Luís XVI, mas justamente para criticar o ato pelo qual as autoridades de Paris confiscaram a justiça popular:

[...] logo que as execuções começaram em setembro, homens da Comuna de Paris, ou próximos dela, intervieram e organizaram a cena do tribunal: juízes atrás de uma mesa, representando uma terceira instância entre o povo que grita "vingança" e os acusados que são "culpados" ou "inocentes"; deliberação para saber o que é "justo"; instância imposta a todos por via autoritária. Será que não vemos reaparecer aqui o embrião, ainda que frágil, de um aparelho de Estado? A possibilidade de uma opressão de classe? Será que o estabelecimento de uma instância neutra entre o povo $e$ os seus inimigos, susceptível de estabelecer a fronteira entre o verdadeiro e o falso, o culpado e o inocente, o justo e o injusto, não é uma maneira de se opor à justiça popular? (Foucault, 1984b, p. 40; grifos meus).

Pierre Victor, apesar do seu maoismo, é quem, no curso desse debate com ares surrealistas, se mostra mais cauteloso em relação a uma forma de justiça que, dito em termos bem crus, se aproxima mais da "lei de Lynch" do que do due process of law que Michel Foucault - à l'occasion, como dizem os franceses - saberá mais tarde brandir com destreza. "É preciso estar seguro de que tal execução, tal ato de vingança, não será um ajuste de contas [...]. Há [...] necessidade de uma instância que normalize o curso da justiça popular, que lhe dê uma orientação" (apud Foucault, 1984b, pp. 41 e 46) - são advertências que Victor sensatamente opõe ao entusiasmo 
de um Foucault (1984b, p. 62) que insiste na tese de que "o tribunal com a sua tripartição entre as duas partes e a instância neutra, decidindo em função de uma justiça que existe em si e para si, [lhe] parece um modelo particularmente nefasto para a [...] elaboração política da justiça popular”.

Evidentemente que, de alguma forma, Foucault (1984b, p. 43) está certo: “A justiça popular reconhece na instância judiciária um aparelho de Estado [...] e instrumento do poder de classe". Afinal, uma "instância" que ainda no século XIX condenava um miserável como Jean Valjean a trabalhos forçados por roubar pão para matar a fome de seus irmãos, como qualificá-la senão como um instrumento de classe no sentido mais descarado do termo? E a sociologia vive insistentemente lembrando que ainda hoje, em qualquer lugar do mundo, a repressão penal se abate seletivamente e com especial vigor sobre os mais fracos. Mas não se trata disso. Trata-se do fato de que 38 Foucault, pelo menos nesse momento, não apenas condena a justiça como ela tradicionalmente se exerce contra os mais frágeis, mas desdenha a própria ideia de justiça como uma "instância neutra" entre as partes em conflito, a possibilidade de que um tribunal, antes de dar a sentença, possa estabelecer a distinção entre "o culpado e o inocente". Numa palavra, ele parece simplesmente opor-se à ideia de que possa existir algo como um tribunal, local onde "se reconstitui uma espécie de divisão do trabalho":

Há os que julgam - ou que dão a impressão de julgar com toda a serenidade, sem estarem implicados. O que reforça a ideia de que uma justiça só é justa se for exercida por alguém exterior à questão, por um intelectual, um especialista da idealidade (Foucault, 1984b, p. 63).

Ora, entre esse "especialista da idealidade" e as partes existem os advogados, outros tantos especialistas. Nesse caso, por 
que permitir que eles venham se intrometer entre a multidão enfurecida e o "culpado"? Mais uma vez, é na prática que o teórico Michel Foucault, enquanto militante, se definia. Isso ocorrerá cinco anos depois desse debate. Em 1977, quando o governo francês se preparava para extraditar o advogado alemão do grupo Baader-Meinhof, então refugiado na França, acusando-o de cumplicidade criminosa com seus clientes, um Foucault (dessa vez atento ao "devido processo legal") escreveu num artigo publicado no Le Nouvel Observateur.

É um direito ter um advogado que fale por você, com você, que lhe permita ser ouvido e preservar sua vida, sua identidade e a força de sua recusa. [...] Esse direito não é uma abstração jurídica, nem um ideal de sonhador, esse direito faz parte de nossa realidade histórica e não deve ser apagado (apud Eribon, 1989, p. 275).

Ou seja: Foucault, à l'occasion, como veremos adiante, empunhava até o discurso do "universal" que não poderia ser "infringido" - mesmo tendo repetidamente encarado qualquer moral de tipo universal como "catastrófica". Apenas um mês antes de sua morte, perguntado sobre uma "teoria do sujeito para os gregos" em entrevista a respeito dos seus últimos livros, observou: "a procura de uma forma de moral que seria aceitável por todo mundo - no sentido de que todo mundo deveria se submeter a ela - parece-me catastrófica” (Foucault, 1984c, p. 137).

Apesar de todas essas declarações, o apelo aos valores de uma moral a que todo mundo deveria se submeter - logo, universal - foi feito pelo próprio Foucault no arremate de um dos empreendimentos políticos mais controvertidos em que se meteu: a revolução iraniana de 1978-1979, saudada por ele com um entusiasmo que seus admiradores ainda hoje não se empenham em destacar - tanto mais que, diferentemente de outras causas que abraçou como a das prisões e da pena 
de morte, dessa vez ele ficou "praticamente sozinho" (Afary e Anderson, 2011, p. 27). Nunca discutido entre nós, o passo em falso foucaultiano merece reflexão. A controvérsia começou em outubro de 1978, quando, de volta de Teerã, aonde foi cobrir a revolução em curso como enviado especial do jornal italiano Corriere della Serra, Foucault, adiantando-se aos seus críticos, escreveu num artigo publicado pelo prestigioso Le Nouvel Observateur: "Já escuto os franceses que riem. Mas eu sei que eles estão errados" (apud Eribon, 1989, p. 302).

Mas a verdade é que eles não estavam. Quando, no curso de 1979, a nova ordem começou a impor-se na antiga Pérsia; quando começou a apedrejar adúlteras e atear fogo em homossexuais; quando tornou obrigatório o uso do véu pelas mulheres, feministas e intelectuais liberais não perderam a ocasião de cutucar o samurai. Um ataque particularmente forte veio de certa Atoussa H. Até hoje ninguém sabe exatamente de quem se tratava. Presumivelmente uma 40 iraniana que vivia no exílio em Paris, Atoussa não poupava Foucault e os demais entusiasmados com o novo regime:

Parece que para a esquerda ocidental, que não tem humanismo, o Islã é desejável... para os outros povos. Muitos iranianos ficam, como eu, perturbados e desesperados só em pensar em um governo "islâmico". Sabemos o que isso significa (apud Afary e Anderson, 2011, p. 156).

As escaramuças continuaram até maio de 1979, quando Foucault se pronunciou pela última vez sobre o assunto, mantendo depois disso um silêncio significativo até sua morte em 1984. Para as finalidades de minha argumentação sobre o humanismo universalista que (quase) não ousa dizer seu nome de Michel Foucault, basta referir uma de suas últimas intervenções: uma carta aberta endereçada ao primeiro-ministro iraniano do novo regime, publicada em abril de 1979, quando as perseguições aos inimigos de Khomeini 
já começavam a assustar o mundo. Destaco alguns de seus trechos:

É necessário - e é urgente - dar àquele que está sendo processado todos os meios de defesa e todos os direitos que forem possíveis. Será ele "obviamente culpado"? Ele tem toda a opinião pública contra ele? Ele é odiado pelo seu povo? Isso, precisamente, confere a ele direitos, muito mais os intangíveis. [...] Para um governo, não pode haver "o mais vil dos homens".

[...] Não se trata de interferência nos negócios internos de um Estado. Aqueles que protestaram em nome de um único iraniano torturado nas profundezas de uma prisão da $\mathrm{SAVAK}^{5}$ estavam interferindo no tema mais universal de todos" (apud Afary e Anderson, 2011, pp. 424-25; grifos meus).

Defendendo-se de incongruência por estar agora assumindo uma postura crítica em relação aos descaminhos que a revolução iraniana tinha tomado, foi preciso: "Certamente não é vergonhoso mudar de opinião, mas não vejo razão para se dizer que essa opinião mudou quando se é contra decepar mãos hoje, depois de ter sido contra as torturas da SAVAK ontem". Por fim, recusando ser considerado um "estrategista", recepciona pela segunda vez no mesmo debate a linguagem iluminista dos valores universais: "Minha ética é 'antiestratégica'. Precisamos ser [...] intransigentes assim que o estado viola universais. É uma escolha simples, mas que dá trabalho" (apud Afary e Anderson, 2011, p. 431; grifo meu). Que dizer a título de conclusão?

$* * *$

Na Introdução do livro dedicado a Michel Foucault, o amigo Paul Veyne diz que poderia tê-lo intitulado Le Samouraï et le poisson

5 SAVAK era a denominação da polícia política do regime deposto. 
rouge (p. 11) - o que não fez. Como não fez, decidi "plagiá-lo". Uma das questões que me ocorreram ao escrevê-lo foi: por que voltar a temas tão repisados? Uma resposta acadêmica - dessas que justificam a existência de um livro argumentando que ele vem preencher uma lacuna - realçaria que, apesar da enorme recepção de um autor como Michel Foucault entre nós, esse é um aspecto da sua obra que não costuma ser discutido nos meios foucaultianos brasileiros. Devo confessar, porém, que a principal razão é de natureza pessoal: como leitor de Foucault, a disjunção aqui trabalhada sempre me causou espécie. As cobranças corriqueiramente endereçadas ao filósofo francês também sempre foram minhas. A leitura do livro de Paul Veyne me forneceu uma boa resposta e me levou a escrever este artigo. Mais do que isso, comecei a pensar, enquanto o redigia, que a disjunção, além de não constituir nenhum mistério, é mais universal do que supomos.

Todos nós nascemos num aquário que não escolhemos.

42 O fato é inafastável. E a infinita maioria de nós se comporta, no geral, de acordo com os padrões vigentes no aquário de nascimento. É a condição necessária até para que exista algo que chamamos de sociedade. Para não ficar entulhando o texto de referências a autores (inúmeros) que, valendo-se dos mais diversos conceitos, já discorreram sobre o assunto, basta lembrar dois nomes classicamente lembrados como fundadores da tradição sociológica, Marx e Durkheim, e o que um e outro disseram, respectivamente, sobre a ideologia (as ideias da classe dominante são, em cada época, as ideias dominantes), e sobre o fato social (maneiras de agir, pensar e sentir exteriores ao indivíduo que exercem sobre ele um poder coercitivo). Ocorre que "dominante" não quer dizer exclusivo, como "coercitivo" não quer dizer onipotente. De maneira análoga, ter nascido no aquário constituído pela máquina panóptica não significa dizer que, mesmo sendo a maior parte do tempo suas engrenagens, não possamos de vez em quando derrapar. Resumindo: enquanto peixinhos dourados, todos nós estamos submetidos às 
"ideias dominantes", somos coagidos pelo "fato social" e fazemos funcionar as correias de transmissão da "máquina" de que somos parte. Enquanto samurais, não. Juntar as duas partes, porém - parodiando Foucault -, dá um trabalho danado!

Ocorre-me um exemplo interessante. Em 1859, num famoso prefácio que escreveu para um livro que terminou abortado (como tantos em sua vida) - Para a crítica da economia política -, Marx elaborou a célebre metáfora topográfica da infraestrutura econômica da sociedade e sua correspondente superestrutura ideológica. O texto é o mais sistemático resumo do que Marx pensava sobre as relações entre "o sistema da economia burguesa", de um lado, e a moral, o direito etc., de outro. Sua importância justifica uma citação longa:

[...] na produção social da própria vida, os homens contraem relações determinadas, necessárias e independentes de sua vontade, relações de produção estas que correspondem a uma etapa determinada de desenvolvimento das suas forças produtivas materiais. A totalidade destas relações de produção forma a estrutura econômica da sociedade, a base real sobre a qual se levanta uma superestrutura jurídica e política, e à qual correspondem formas sociais determinadas de consciência. [...] Não é a consciência dos homens que determina o seu ser, mas, ao contrário, é o seu ser social que determina sua consciência (Marx, 1974, pp. 135-36; grifos meus).

Quem escreveu isso era um samurai. Como tal, Marx cultivou a vida inteira o projeto de destruir o capitalismo e, com ele, a consciência burguesa correspondente. Mas o guerreiro era também um pai de família preocupado com o futuro das filhas. Uma delas se chamava Laura, que, em 1866, envolveu-se com um revolucionário como seu pai: Paul Lafargue. Isso inquietou o "mouro", que escreveu para o futuro genro em termos que poderiam ter sido subscritos por um peixinho burguês: 
Antes dos acertos finais de seu relacionamento com Laura, eu preciso ter algumas informações importantes acerca de suas condições econômicas [...] Você sabe que eu consagrei toda minha fortuna à causa revolucionária. Não me arrependo; muito ao contrário. Se eu tivesse que iniciar minha carreira novamente, faria o mesmo. Apenas não me casaria. Até onde estiver ao meu alcance, desejo proteger minha filha dos abismos em que a vida da mãe dela foi despedaçada (Marx apud Sperber, 2014, p. 454).

Para finalizar, lembraria que essas não são aporias apenas dos clássicos: são de todos nós. Nós que precisamos votar escolhendo alguém numa lista de candidatos que não elaboramos; que temos contas de água e luz a pagar; que ganhamos o pão no interior de uma sociedade em que não escolhemos nascer. Como cidadãos implicados nas suas engrenagens, quantas vezes não as azeitamos? E quando empunha44 mos o sabre do samurai, quantas vezes não temos de nos defender do sarcasmo dos peixinhos dourados com quem convivemos? Assim, este artigo foi também escrito pensando nos dilemas práticos a que nos expomos quando decidimos cutucar as paredes do aquário confortável em que estamos imersos. Pensemos, por exemplo, numa questão que apresenta especial e dramática relevância no país e no tempo que estamos vivemos: a questão dos direitos humanos.

O militante de direitos humanos, num país como o Brasil, constitui um bom objeto para pensarmos sobre a disjunção entre sujeito empírico e sujeito epistemológico. Como samurai, ele se insurge contra certas abominações bem nossas, e, ao elevar a voz para protestar contra a violência policial que se abate sobre um ladrão, costuma ouvir dos seus concidadãos a clássica pergunta: "e se fosse com você?". Ele possui um conhecimento sociológico sobre as causas estruturais da violência urbana que amedronta as pessoas normais, e sabe que de pouca coisa adianta lutar contra os seus efeitos. Leitor de 
Michel Foucault, tem uma visão crítica sobre o "panoptismo" que se instalou nos espaços públicos onde circula e chega até os elevadores dos prédios em que mora, onde se defronta com uma câmera de circuito interno e a odiosa interjeição: "Sorria! Você está sendo filmado!"; também tem análoga visão negativa sobre os processos de "criminalização da pobreza" veiculados por nossos infames "programas policiais" e reproduzidos pelo senso comum. Mas, como é também um peixinho dourado, o militante tem medo, vive "enjaulado" e não se atreve a entrar à noite numa favela mal afamada...

Durante os nossos "anos de chumbo", no inesquecível jornal O Pasquim, o cartunista Ziraldo tornou famosa a figura de um sujeito de paletó amparado numa parede e transpassado por uma enorme faca que lhe entrava pelas costas e saía pelo abdome. O sujeito olhava o leitor com um riso escancarado, mostrando todos os dentes, mas o tranquilizava: "Só dói quando eu rio". Acho que essa imagem vem a calhar para ilustrar o desconforto do peixinho dourado quando se dispõe a ser samurai: "Só dói quando eu penso".

\section{Luciano Oliveira}

é doutor em Sociologia pela Escola de Altos Estudos em Ciências Sociais (EHESS), Paris, França; professor aposentado de Sociologia Jurídica da Faculdade de Direito do Recife, e professor do Departamento de Ciências Jurídicas da Universidade Católica de Pernambuco.

\section{Bibliografia}

AFARY, J.; ANDERSON, K. B. 2011. Foucault e a Revolução Iraniana. São

Paulo: Realizações Editora.

BENTHAM, J. 2000 [1787-1791]. O panóptico. Belo Horizonte: Autêntica. CASANOVA, G. 1946. Memórias. Rio de Janeiro: José Olympio. Tomo 3. ERIBON, D. 1989. Michel Foucault. Paris: Flammarion.

EWALD, F. 1984. Le joueur de savoirs. Dossier Michel Foucault. Libération,

Paris, 30.06, 1 juil 1984.

FOUCAULT, M. 1977. Vigiar e punir. Petrópolis: Vozes. 
1984a. História da sexualidade I - A vontade de saber. Rio de Janeiro: Graal.

. 1984b. Microfísica do poder. Rio de Janeiro: Graal. 1984c. O retorno da moral. In: ESCOBAR, C. H. (org.). Michel

Foucault (1926-1984). O dossier: últimas entrevistas. Rio de Janeiro:

Taurus.

1987. História da loucura. São Paulo: Perspectiva. 1999. As palavras e as coisas. São Paulo: Martins Fontes.

MARX, K. 1974 [1859]. Para a crítica da economia política. São Paulo:

Editora Abril.

PERROT, M. (org.). 1980. L'impossible prison: recherches sur le système pénitentiaire au XIXe siècle. Paris: Seuil.

ROUANET, S. P. 1997. As razões do Iluminismo. São Paulo: Companhia das Letras.

SPERBER, J. 2014. Karl Marx: uma vida do século XIX. Barueri, SP: Amarilys. VEYNE, P. 2008. Foucault: sa pensée, sa personne. Paris: Albin Michel.

VIDAL-NAQUET, P. 1986. Préface. In: BENASAYAG, M. Utopie et liberté. Paris: La Découverte. 


\title{
O PEIXINHO dOURADO E O SAMURAI: SUJEITO EMPÍRICO E SUJEITO EPISTEMOLÓGICO EM MICHEL FOUCAULT
}

\author{
LUCIANO OLIVEIRA
}

Resumo: Michel Foucault foi um dos nomes mais importantes do anti-humanismo teórico derivado do estruturalismo. Ao mesmo tempo, foi um aguerrido militante dos direitos humanos, inserindo-se na tradição humanista derivada do Iluminismo. Parece assim haver uma contradição entre as duas atitudes: a teórica e a prática. $\mathrm{O}$ artigo sustenta que não. Que a primeira atitude é própria do que chama sujeito epistemológico, e que a segunda é própria do que chama sujeito empírico. Uma e outra podem ser encontradas no mesmo indivíduo, e não apenas em Michel Foucault, porque todos nós somos capazes de ser as duas coisas ao mesmo tempo.

Palavras-chave: Michel Foucault; Anti-Humanismo; Sujeito Epistemológico.

\section{THE GOLDFISH AND THE SAMURAI: EMPIRICAL AND EPISTEMOLOGICAL SUBJECT IN MICHEL FOUCAULT}

Abstract: Michel Foucault was one of the most important antihumanism theoreticians deriving from structuralism. At the same time, he was a fighting militant for human rights, hence being a member of the humanist tradition of Enlightenment. It seems there is a contradiction between these two attitudes: the theoretical and the practical. This article denies it. Accordingly, it holds that the first attitude is proper to the "epistemological subject", while the second one pertains to the "empirical subject". One as much as the other can be found in the same individual, not only in Michel Foucault, for all of us are capable of being both at the same time.

Keywords: Michel Foucault; Anti-Humanism; Epistemological Subject.

Recebido: 25/03/2016

Aprovado: 07/10/2016 